\title{
Family and Its Role in a Healthy Education of Adolescent
}

\section{Dritan Ceka}

Phd Candidate, European University of Tirana, Faculty of Social Sciences dritanceka@hotmail. com

Prof. as. dr. Fatmir Vadahi

Deputy Rector of the University of Shkodra, fatmirvadahi@gmail. com

Msc. Anila Jaku

University of Shkodra,"Luigj Gurakuqi" anila2010@hotmail. co. uk

\begin{abstract}
Over the centuries the family is going through constant transformations as a result of the continuous process of evolution. It forms its shape under the conditions of life which dominate in a certain place and a certain time. Family in our country, has quickly changed with the social changes that are characteristic of our historical period of transition given the circumstances as a society we have experienced. Society regardless stages of its transformation or transition from one system to another, can not evade what is the basis of the continuation of its journey educating seed with acceptable norms of morality, education and culture necessary for the conduct of civilized life. Today there are several factors that affect adolescents and education. Today our Society in facing various difficulties in the education of their offspring. As in Albania and Montenegro today we rise or schooled teenagers in conditions completely different from their predecessors fathers and mothers. Today the competent authorities do not exercise their influence in Institutions of education enough so the family is difficult to educate teens genuine requirements Notwithstanding her desire that their offspring be better. Today in the vicinity of schools have full local where sold alcoholic beverages and tobacco. Given the fact that this problem among adolescents in Ulcinj and Shkodra did not take one by a survey earlier this issue we decided to develop a questionnaire research with adolescents in these two cities close to the geography, but in different states with a not distant geographical longitude.
\end{abstract}

Keywords: family, education, health, adolescent, health behaviors

\section{Introduction}

Modern Times is complex and difficult in terms of education for the family. Never before as today has been so difficult to educate adolescents. Apparently the education of children outside the education paradigms of the past authoritarian not automatically process is easy. Education in freedom, in the context of family democratize brings "is difficult for the family," which created a social situation where many parents feel overwhelmed by the "critical level" education that are not able to understand what happened with family and their children (Tushi, 2012). Many parents are confused and psychologically of behavior before their children. Often they ask concerned about the educational situation that takes place in our families. They want to know if children are getting well educated or family is left behind with traditional stuffs. The old roles and relationships between parents and children, looking in vain old settings be moral and educational functions of the traditional family. Situation educational violence is blurred because the old principles of the education system, operated traditionally in it in the past, in terms of the modern family, mixed doubt roles and positions and relationships between parents and children are not the same ones that they have been especially traditional family. Today should understand deeply that way impressive, difficult situations in relationships with members of the family, regarding communications education to parents on their children, is not only due to differentiated time parents with their children but for reasons time of conceptual differences, but also the lack of social patience. At a time when other roles and social structures fade when their influence 
on man becomes spontaneous and indirectly, of course the role of the family, especially with regard to education of children increased significantly.

\section{Methodology paper}

\section{The sample}

Selection of samples for the study were adolescents 11-18 years of age in the Municipality of Ulcinj and at the Shkodra. This study was conducted in two states, the number of participants in this study was 1005 students (teens) high school, in the region of Ulcinj $(\mathrm{N}=739)$ and Shkodra $(\mathrm{N}=266)$. Participants in research by $48.6 \%(\mathrm{~N}=488)$ were male and $51.4 \%$ $(\mathrm{N}=517)$ women. Classes were selected at random, as in primary schools as well as schools of both cities.

\section{The objective of research}

To assess the risk factors associated with healthy adolescent behavior.

To assess the degree of coherence between the scale of assessments in healthy adolescent behavior with the scale of the health care family.

To assess the degree of coherence between the scale of assessments in healthy adolescent behavior with the degree of relationship with parents.

\section{The purpose of the research, research questions and hypotheses}

The purpose of this research is to assess the level and introduce healthy behavior among adolescents aged 11-18 years in the city of Ulcinj compared with those of Shkodra, according to information from the adolescents themselves, as well as assessing the impact of demographic factors such as age, gender, residence, number of household members, Real number of children within the family, parental education and employment.

\section{It raises the hypothesis that this research are:}

The hypothesis of this research are dictated by the sight of world literature and at the same time by observing the latest trends of young people in relation to their appearance and social image.

\section{H-1. Population of adolescents 11-18 years reported higher levels of importance to health}

$\mathrm{H}-2$. Teenagers who highly value healthy behavior are more engaged in physical activities and pay attention to healthy food.

\section{Research Design}

The study used two standardized questionnaires. The survey was conducted in 6 schools in the Municipality of Ulcinj and in 6 schools in the Municipality of Shkodra. Questionnaires were distributed to schools by their students in collaboration with the class teacher. After collecting the questionnaires were collected and placed in a box together, where besides us there is no one else had access.

\section{The working population}

The population of this problem is large and heterogeneous. Since this problem is not able to study it in the population, I make a sample I am a champion chosen, especially in order to investigate the problem. Population of this problem are pupils of the Municipality of Ulcinj and Shkodra. As the number of individual cases of salaries are great that I am oriented to study this problem only in high school classes. 


\section{The theoretical treatment of the problem}

Family is defined as basic social cells and one of the most complex, older groups and socially sustainable. It lies very different sides of human life, and therefore has a wealth of meanings and interpretations philosophical, sociological, psychological, educational, social, economic and legal for. Family is a group of biological and educational. This is its fundamental social content from creation to the present day. Family is the first bio-psychological-social to which create, develop and educate the child. In the bosom of family, the child develops and affirmed as being bio-psychosocial attentive. Held in psychological view, learn to speak, think, and work is reduced, exercise observe, perceive, recognize themselves, others and the world around. Under the influence and help of parents and other family members, develops abilities, skills and habits before life forms. Through social interaction with mother and interaction with family members, especially playing with other children and adults, and imitating the behavior and work of family members, it develops mental forces, observations and perceptions skills etc. (Brada, 2012). The family is the first school, even irreplaceable child. Educational practices and psychological scientific inquiry have proved that adult child in the family environment of the entire psychophysical development experiences, is communicative, more easily adapt to new social environment. The biological function of the family is reflected in the satisfaction of sexual urge individuals, meeting the emotional needs, reproduction, the procreation and education of new generations, or extension of the human species. Family historical development of its function of education has not always been the same intensity of which depends not only on it, but in the circumstances the content, nature and structure of social relations in which it was held.

\section{Theoretical concepts on the family}

The complexity of the nature and functions of the family in society and in human development, it is natural to have happened, many theories and studies on family and its history come to know and understand human origins and existence.

Today there is no complete theory which defines the family in all its details. Existing research is not sufficient for processing the theoretical principles that will highlight how family history been properly through the years. The social function of the family is reflected in the education and care for offspring, so that protection from attacks and threats to individual freedom. Today, the function of the family has changed, but it still remains an important social institution, which plays a major role in the life of every individual and in every social system.

\section{Family Types}

Family represents one complex creations with social standing and consists of various elements of biological origin, social etc. Society in general and the family in particular are composed of concrete individuals. Family is presenting cell or basic element, but also institutions and social groups. The family institution is not only natural but also the social institution. The social function of the family is quite broad.

There are many classifications of families based on different criteria:

a) The traditional family in tribal communities many different subspecies,

b) The patriarchal family of old civilizations, which all their needs not meet with productivity in its district.

c) before the industrial family, traditional one.

d) industrial family, which is characterized by on the social groups.

\section{Family and education of children}

Modern Times is complex and difficult in terms of education for the family. Never before as today has been so difficult to educate adolescents. Apparently the education of children outside the education paradigms of the past authoritarian not automatically process is easy. Education in freedom, in the context of family democratize brings "is difficult for the family," which created a social situation where many parents feel overwhelmed by the "critical level" education that are not able to understand what happened with family and their children. Many parents are confused and psychologically of behavior 
before their children. Often they ask concerned about the educational situation that takes place in our families. They want to know if children are made difficult or family is left behind traditional and old roles and relationships between parents and children, looking in vain old settings be moral and educational functions of the traditional family. Situation educational violence is blurred because the old principles of the education system, operated traditionally in it in the past, in terms of the modern family, mixed doubt roles and positions and relationships between parents and children are not the same ones that they have been especially traditional family. Today should understand deeply that way impressive, difficult situations in relationships with members of the family, regarding communications education to parents on their children, is not only due to differentiated time parents with their children but for reasons time of conceptual differences, but also the lack of social patience.

\section{The family as an educational factor of teenager}

In sociological doctrines family is the most important agenda of personality in action affects all direct and indirect starting even eating sleeping and other impacts of expression, purity, etc. Family is a factor of the child spends most big in the beginning so that affects a child's development. The human being is born as human sociological although there certain predisposition or born to become social beings to comprehend sociologically it created in social. Family's impact is the primary community because it is the first human group most important and closest. It is the prototype of every other community, social, because the family placed permanent connections, emotionally close, and versatile solidarity among members. The family created by the establishment of a marriage between a man and a woman, in which children are born and which remains the formal structure of family reunification. Is the primary group and intimate community while turning social institution somewhat larger society (Mitrovic, 1995).

\section{The role of the family in the education of adolescents}

The problems of education are quite difficult at different stages of adolescent development, to touch on the role of special and irreplaceable family in the upbringing of the younger generation. Family education is as old as the family itself. He long time ago existed in the distant past of science education. Even today this education is done by very many parents, educated or not, without knowing the science of education, even in some cases by educating children better than some who know this science. Family plays a major role for the individual because, through it, the child enters the society gradually becomes an element of civilization. Family feeds and other materials to meet the requirements of spiritual showing special care for them. Family atmosphere affects children and adolescents in many ways, forming their very personality traits, attitudes that keeps others, to work, property, society etc. Relations and cooperation between family members contributes to the creation of new family relationships, the degree of openness or other attitudes, attitudes toward family members belonging or in their society. Early childhood teenager knows only lifestyle of the parents. A few years later he will go after the life of the parents. A few years later he will go after the following examples influence of others. Child relinquishes some of his desire to honor the rules of the family and society, even when not like these rules. He is afraid not to apply because they can destroy the shroud parents, but there are times when the personality of adolescents swaying, holding within personality his another "I", which becomes even more wild when he comes to understand better the duality of personality his (Kraja, 2008). It is known that the house does not become class, no organized process for everything, it is usually in the school at the time of the learning process.

\section{Education as a factor of development of teenagers personality}

Social factors are very numerous and complex. They cause very different impacts. However, all the effects of this type do not have the same importance for the development of personality. Greater importance upon those impacts are relatively more stable and somewhat organized. In these views education has a special place. Its importance for the development of personality that greater education is separated from frame the impact of social surroundings and prominent which as one of the special factors crucial in the development of each individual. There is a range of our general provisions for which do not lack the basic conditions for the development of the largest number of individuas, members of a community.

\section{Education and health education of adolescents}

In the civilized world education and health education are treated as medical and educational scientific discipline that has as its object the establishment and activity of study and advancement of health culture of the people as a precondition for 
protecting his health. They treat health as wealth and physical value of the material and cultural, family and all the people. In this feature education and school health education of youth is of paramount importance. The healthy formation of youth is a prerequisite of development and security material and cultural nation. Education and health education aims and tasks: to help students, teachers and parents to acquire basic knowledge on physical, mental and social development of man on the dangers facing shaped the disease, injuries, and the possibility and how to protect it from these at all stages of human development, countries, conditions in various forms of life and action of man, to acquire knowledge about hygiene, personal and collective, as well as on the role, function, duties and importance of medical services for the protection of health.

\section{The adolescent healthy education}

Adolescence is a dynamic period of growth and physical development, psychological and social connecting passage from childhood to adulthood, differing significantly from these two age groups. Adolescence includes ages between 10-19 years. The overall goal of improving adolescent reproductive health includes: responsive relationships and equal between boys and girls; reducing the incidence of pregnancy before the age of puberty; prevention and treatment of sexually transmitted infections and HIV, improving the status of girls and women in society.

Adolescence, in particular puberty, is a period of rapid development, when young people acquire new skills and face many situations, which are not only development opportunities, but also a risk to their health and welfare. Adolescence is a time of mental and psychological suitability, where young people develop their identity, intimacy, relationships with peers and intensify gradually became independent from the family. Adolescence is also a time when discovered new experiences and influences that left their mark on the thinking, ideas and actions. The behavior of teenagers during those years can lead to the onset of sexual relations, abuse of alcohol, tobacco and other substances. Peer pressure can lead to the onset of risky behaviors. Lack of proper access to appropriate services and lack of supportive environment can affect their health and development. The strategy for maternal, child, and adolescent reproductive health. The most significant health challenges during adolescence are: accidents, trauma, injury, sexual and reproductive health, risky behaviors associated with the use of harmful substances, nutrition, physical activity and mental health. Tobacco use is at a high level in this age group and there is an increased prevalence among girls. Excessive alcohol consumption among adolescents is associated with road traffic accidents. Teenagers and young adults are most at risk to be infected with various diseases and nw tw particular with HIV. However, the promotion of good health, not just removal of risky behaviors. Our investment for future generations should also promote healthy ways of living. Adequate physical activity and balanced nutritional diet in adolescence are the cornerstone to good health. Interventions to achieve these are particularly important to reduce youth obesity.

\section{Health care in teens}

Adolescence is a period of about 10 years. until the late teens or early 20 s, during which children go through changes remarkably physical, intellectual and emotional. Monitoring children during this period presents a challenge for both parents and doctors. Fortunately, most adolescents in good physical health, but psychosocial difficulties are common, because even normal individuals struggling with issues of personality, independence, sexuality and interpersonal relationships. Most teens have a constant preoccupation with the question "Who am I, where I go and what my relationship with all the people in my life?". Many forms of unhealthy behaviors that start during adolescence (eg, smoking Tips for parents to influence behavior change skills and application of the rules of healthy eating:

- use oil in small quantities in cooking

- take into account the size of the food pieces

- use at every meal fruits and vegetables

- use fish at least $2 x$ a week

- adolescents should always remove the skin from chicken meat

- use lean meats and limit consumption quantities 
- use of integrated products

- have reduced the

Introduction of consumption of sweetened drinks at

Analysis and interpretation of records

Table No. 1. Pearson correlation results for healthy behavior correlated variables

\begin{tabular}{|c|c|c|}
\hline & & Healthy behavior \\
\hline \multirow[t]{3}{*}{ Weight } & r & -.076 \\
\hline & p & 018 \\
\hline & $\mathrm{N}$ & 969 \\
\hline \multirow{3}{*}{ Do you drink alcohol } & r & $.086^{*+}$ \\
\hline & $\mathrm{p}$ & .007 \\
\hline & $\mathrm{N}$ & 1005 \\
\hline \multirow{3}{*}{ Do you smoke } & r & $.119^{*+}$ \\
\hline & $\mathrm{p}$ & .000 \\
\hline & $\mathrm{N}$ & 1005 \\
\hline \multirow{3}{*}{ Do you deal with physical activity } & r & $.542^{* *}$ \\
\hline & $p$ & .000 \\
\hline & $\mathrm{N}$ & 1005 \\
\hline \multirow{3}{*}{ Feeding } & r & $364^{* t}$ \\
\hline & p & .000 \\
\hline & $\mathrm{N}$ & 1005 \\
\hline \multirow{3}{*}{ Relationship with father } & r & $.172^{* *}$ \\
\hline & p & .001 \\
\hline & $\mathrm{N}$ & 982 \\
\hline \multirow{3}{*}{ Relationship with mother } & r & $166^{\star \star}$ \\
\hline & $p$ & 001 \\
\hline & $\mathrm{N}$ & 1001 \\
\hline
\end{tabular}

Linear regression analysis was used to determine if weight, drinking alcohol, smoking, dealing with physical activities are important for prediktor healthy adolescent behavior. Initially seen the degree of correlation between the values of healthy behavior with weight, physical activity, nutrition, smoking and drinking alcohol. The results show that the weight is found in negative correlation $(r=-.076)$. although this correlation is statistically valid it is weak. Correlation shows how much weight are the smaller adolescents is their health care. While drinking alcohol and smoking were positively related to healthy behavior, but it is worth noting that the maximum values in these two instances show that teens do not drink alcohol or smoke. While the positive correlation and nutrition activities indicate that as many healthy behaviors as more young people practice sports and pay attention to nutrition health. And that this correlation is moderate and statistically significant (Table 1). 
Tabela 2. Summary results of the regression model

\begin{tabular}{lllll}
\hline Model 1 & $\mathrm{R}$ & $\mathrm{R}$ Square & Adjusted R Square & $\mathrm{p}$ \\
\hline $\begin{array}{l}\text { Drinking } \\
\text { alcohol }\end{array}$ & $.086^{\mathrm{a}}$ & .007 & .006 & .001 \\
\hline Smoking & .119 & .014 & .013 & .001 \\
\hline Feeding & .364 & .132 & .131 & .001 \\
\hline $\begin{array}{l}\text { Physical } \\
\text { activity }\end{array}$ & .542 & .293 & .293 & .001 \\
\hline
\end{tabular}

a. Prediktor: (Konstant) Drinking alcohol; Smoking; Feeding; Physical activity.

It shows that smoking, alcohol, dealing with physical activity and nutrition healthy are predictor significant variance of bringing healthy but the forecast is not too strong to explain the behavior of healthy Just $0: 07 \%$ of the variance behavior of healthy explained drinking alcohol $[R s=.007, \beta(39.6, .56)=.08, p=.007]$; smoking only explains $0.014 \%[R s=.014, \beta$ $(39.5, .49)=.11, p=.001]$; getting physical activity explains $29.3 \%$ of variance $[R s=.293, \beta(32.9, .91)=.54, p=.001]$ and nutrition explains $13.2 \%$ of variance $[R s=.132, \beta(36.2,1.0)=.36, p=.001]$

These results indicate that high teens who value healthy behavior are more engaged in physical activities and pay attention to healthy food.

When the model is added as prediktor weight which only explained variance only 0:06\% of healthy adolescent behavior have $46.5 \%$ of the variance explanation by the combination of these five factors.

Tables 3. Results of regression analysis where the dependent variable is healthy adolescent behavior.

\begin{tabular}{|c|c|c|c|c|c|c|}
\hline & \multicolumn{2}{|c|}{ Unstandardized Coefficients } & \multirow{2}{*}{$\begin{array}{l}\text { Standardized } \\
\text { Coefficients } \\
\text { Beta } \\
\end{array}$} & \multirow[b]{2}{*}{$t$} & \multirow[b]{2}{*}{ Sig. } \\
\hline & & B & Std. Error & & & \\
\hline \multirow[t]{5}{*}{ Ulqini } & (Constant) & 14. 399 & 1.455 & & 9.893 & .000 \\
\hline & $\begin{array}{l}\text { Adolescent health } \\
\text { values }\end{array}$ & 1. 012 & .034 & .747 & 29.443 & .000 \\
\hline & $\begin{array}{l}\text { Healthy behavior in } \\
\text { the family }\end{array}$ & -.002 & .010 & -.006 & -.235 & .814 \\
\hline & $\begin{array}{l}\text { The importance of } \\
\text { the relationship with } \\
\text { father }\end{array}$ & -.037 & .030 & -.034 & -1.241 & .215 \\
\hline & $\begin{array}{l}\text { The importance of } \\
\text { the relationship with } \\
\text { mother }\end{array}$ & 036 & .028 & 035 & 1. 281 & .201 \\
\hline Shkodra & (Constant) & 10. 932 & 2. 546 & & 4. 294 & .000 \\
\hline
\end{tabular}




\begin{tabular}{|l|l|l|l|l|l|l|}
\hline $\begin{array}{l}\text { Adolescent health } \\
\text { values }\end{array}$ & .873 & .059 & .677 & 14.850 & .000 \\
\hline $\begin{array}{l}\text { Healthy behavior in } \\
\text { the family }\end{array}$ & .022 & .017 & .056 & 1.284 & .200 \\
\hline $\begin{array}{l}\text { The importance of } \\
\text { the relationship with } \\
\text { father }\end{array}$ & .126 & .049 & .121 & 2.581 & .010 \\
\hline $\begin{array}{l}\text { The importance of } \\
\text { the relationship with } \\
\text { mother }\end{array}$ & .094 & .055 & .080 & 1.709 & .089 \\
\hline
\end{tabular}

These results indicate that high teens who value healthy behavior are more engaged in physical activities and pay attention to healthy food.

When the model is added as prediktor weight which only explained variance only 0:06\% of healthy adolescent behavior have $46.5 \%$ of the variance explanation by the combination of these five factors. While healthy family behavior is checked for its variance prediktibilitetin of healthy adolescent behavior. Healthy behavior in the family although it is showing a significant prediktor statistically Veccia she explains $0.07 \%$ of the variance of healthy behavior in adolescents.

The relationship with the father and mother entered in the regression model showed that the relationship with his father explained variance of $0.03 \%$, while $0.2 \%$ relationship with his mother. when both are included in the model relationship together they explain $0.4 \%$ of variance are important preditkor healthy behavior.

Regressionit analysis is made for healthy adolescent behavior with four scales considered in this research and look at the table when these rates are combined in just the scale model "values of health for adolescents" preserves signifikancen $p$ $<.05$ and no other steps prediktorë are important for healthy adolescent behavior. But these factors combined together explain $54.8 \%$ of variance healthy behavior (Rs $=.548$ ).

Except for the cities analyzed as shown in Table 3. see the city of Shkodra and maintains the relationship with his father as a predictor signifikancën. This model explains $55.9 \%$ of variance healthy behavior for teens Ulcinj (Rs $=.559)$ and and 54. $9 \%$ (Rs $=.549)$ for adolescents Shkodra. 
Tables 4: Të dhënat përshkruese për Sjelljen e shëndetshme me moshën e adoleshentëve.

\begin{tabular}{lllc} 
Age in years & Medium & Standard deviation & N \\
\hline 12.00 & 2.13 & .640 & 15 \\
13.00 & 2.59 & .532 & 105 \\
14.00 & 2.51 & .640 & 215 \\
15.00 & 2.61 & .564 & 178 \\
16.00 & 2.55 & .597 & 151 \\
17.00 & .572 & 147 \\
18.00 & 2.58 & .594 & 194
\end{tabular}

Kruskal-Wallis test was used to see whether age influences adolescents reporting values on the scale "values of health for adolescents". The results show that $p=.04$, indicating that the effect is significant, and this is performed post hoc analysis (LSD) to see which age the differences between larger in relation to healthy behavior. The results show that significant differences are between the age of 12 with all other ages up to 18 years. Adolescents aged 12 years have the lowest annual average growth rate of healthy behavior than those of older ages.

Tables 5: Hi square test results for adolescents coming from Ulcinj and Shkodra in their responses to the "values of health for adolescents".

\begin{tabular}{|c|c|c|c|c|c|c|}
\hline & Value & $d f$ & $\begin{array}{l}\text { Asymp. } \\
\text { Sig. } \\
\text { sided) }\end{array}$ & $\begin{array}{l}\text { Exact Sig. } \\
\text { (2-sided) }\end{array}$ & $\begin{array}{l}\text { Exact Sig. } \\
\text { (1-sided) }\end{array}$ & Point Probability \\
\hline $\begin{array}{ll}\text { Pearson } & \text { Chi- } \\
\text { Square } & \end{array}$ & $2.572^{\mathrm{a}}$ & 2 & 0.276 & 0.275 & & \\
\hline Likelihood Ratio & 2. 604 & 2 & 0.272 & 0.282 & & \\
\hline Fisher's Exact Test & 2. 588 & & & 0.273 & & \\
\hline $\begin{array}{l}\text { Linear-by-Linear } \\
\text { Association }\end{array}$ & 1. $487^{\mathrm{b}}$ & 1 & 0.223 & 0.228 & 0.123 & 0.023 \\
\hline $\mathrm{N}$ of Valid Cases & 1005 & & & & & \\
\hline
\end{tabular}


The data were analyzed with hi square test for adolescents coming from Ulcinj and Shkodra in their responses to the "values of health for adolescents have shown that there is no correlation in the distribution of responses in reporting" values of health for adolescents "with the city $\mathrm{X} 2(2)=2: 57, p<.223$.

In the table we see that in general we have a total of $5.2 \%$ of participants who responded to the category "Not at all important" and 3. $8 \%$ of them are represented by the Ulcinj adolescents and 1. 4\% from Shkodra. Ners in the category of very important responses have $59 \%$ of adolescents and 64 . 3\% Ulcinj. While the overall total of $43.4 \%$ of the responses have Ulcinj adolescents and $17 \%$ of adolescents from Shkodra who are represented with more important category.

Table 6. Annual average growth rate, standard deviation and variance analysis results for healthy behavior and drinking alcohol.

\begin{tabular}{|l|l|l|l|}
\hline & & & \\
\hline Drinking alcohol & M & SD & N \\
\hline Every day & 39.70 & 5.14 & 10 \\
\hline 6 days a week & 41.83 & 6.33 & 6 \\
\hline 5 days a week & 39.66 & 2.88 & 3 \\
\hline 4 days a week & 41.66 & 4.93 & 3 \\
\hline 3 days a week & 42.33 & 4.27 & 6 \\
\hline 2 days a week & 41.00 & 3.30 & 12 \\
\hline 1 days a week & 40.86 & 4.36 & 37 \\
\hline 1 in two weeks & 41.96 & 2.75 & 55 \\
\hline Every month or less & 41.10 & 4.14 & 124 \\
\hline I do not drink alcohol & 41.93 & 3.68 & 749 \\
\hline$F(9,995)=1.3, p=.206, \eta^{2}=0.012$ & & & \\
\hline
\end{tabular}

As shown in the table, healthy behavior had the highest average in the group of adolescents who do not drink alcohol $(\mathrm{M}=$ 41. 9, SD = 3.6), compared with other groups. Teenagers who do not drink alcohol have been shown to have healthier behavior than those who drank alcohol and this difference was statistically valid $(F(9,995)=1.3, p=.206, \eta 2=0.012)$.

\section{Conclusion}

This study was led mainly by development theories which describe the needs of children as they go through during adolescence. The basic belief is that children have special needs at every stage of life, based on growth and development that is expected to occur during that period. Stages of adolescence, like others before it, has its own set of development achievements which should be achieved within a reasonable time in order to optimize the development. In order for adolescents to do this they must adjust their roles in their relationships with their parents, becoming more equal over time. In fact the whole goal of adolescence is to turn the child into a functional adult who is no longer dependent on caregivers. This is a great road for parents and teens as transformed their role requires frequent adjustment and renegotiation. The first family is the basic institution of society, family education takes place not in school, but naturally, the full family provides appropriate educational conditions, family education relies heavily on the family tradition and beyond. In the family used special educational methods, which can avoid the educational care for the younger generation, in numerous conversations and random, individually developed to promote the creation of emotions and beliefs, without excluding the prevention of the negative. 


\section{References}

Beveridge, S., (2005). Children families and school, Developing partnership for inclusiveeducation, New York.

Brada, Riza, (2012) Edukimi mendor e moral i fëmijës, Prishtinë.

Bean, Anita, (2007) Si t'i ushqejmë fëmijët në mënyrë të shëndetshme, Max, Tiranë.

Brada, Riza, (2003) Pedagogjia Familjare, Pej.

Brković, Aleksa (2011) Razvojna psihologija, Regionalni centar za profesionalni razvoj zaposlenih u obrazovanju, Čačak.

Deva-Zuna, Afërdita, (2009) Partneriteti Shkollë-Familje-Komunitet, Prishtinë.

Dizdari, Islam, Aliu Bahri, (2007) Edukimi Familjar, Logos, Shkup.

Hoxha, dr. Mit'hat \& Ledina Xhakollari, (2010) Psikologjia e zhvillimit,Vllamasi, Tiranë.

Kraja, dr. Musa, (2008) Sa merresh me fëmijën tënd, Geer, Tiranë.

Kraja, dr. Musa, (2008) Pedagogjia e Zbatuar, Geer, Tiranë.

Kërneta, dr. Lubomir dhe Potnonjak, dr. Nikolla, (1965) Fillet e Pedagogjisë, Beograd.

Orhani, dr. Zenel, (2011) Psikologjia e Emocionave, Vllamasi, Tiranë.

Tushi, Gëzim,(2012) Martesa, Familja, Seksualiteti, Natyra, Tiranë.

Rot, dr. Nikolla, (1982) Psikologjia e përgjithshme, Prishtinë.

Vulić-Prtorić, A. (2002) Obiteljske interakcije i psihopatološki simptomi u djece i adolescenata, Suvremena psihologija, 5/1, $31-51$.

Woolfolk, Anita, (2011) Educational Psychology, Pearson Education, Boston. 